\title{
Teacher Preparation in Scotland
}




\section{Praise for Teacher Preparation in Scotland}

'This volume is to be warmly welcomed and includes contributions by many of the leading teacher education researchers in Scotland. Teacher preparation and development have long been seen as a key element of Scottish society and culture. In the twenty-first century we have seen very significant developments in the nature of that provision. These innovations are very well covered in this book but they are underpinned by some excellent historical scholarship. These elements are combined to create what will be the definitive account of teacher education in Scotland for many years to come'.

\section{Ian Menter, Emeritus Professor of Teacher Education, University of Oxford}

'This book is an important addition to the study of teacher preparation providing an in-depth exploration of teacher preparation in Scottish education. It combines historical perspectives with discussions of current developments, analysing the challenges faced by teacher education. Teacher preparation in Scotland, unlike other systems in the UK, is solely university-based. The early chapters provide a historical overview of the place of the discipline of education in universities, the development of government policy on teacher training, the establishment of colleges of education and then and more recently in the 1990s, through a series of mergers, university-based teacher preparation. What will strike the reader is how many of the issues that teacher educators grapple with today are in evidence in earlier phases. The book provides a comprehensive coverage of current key issues from a Scottish perspective. Each chapter deals with a specific dimension and the book as a whole provides a comprehensive coverage of the current ITE landscape, highlighting some of the ongoing issues such as university programmes, partnerships and placements as well as innovative practice. The book reflects on the central question facing all teacher educators, where should teacher preparation happen, where do student teachers learn best? The book is an important reference work drawing on policy, research and the scholarly literature'.

Professor Christine Forde, Emeritus, University of Glasgow

'There exists a sustained scrutiny on how well initial teacher education prepares individuals for the realities of life as a teacher. The contributions in this comprehensive overview of the history and development of teacher education in Scotland present an opportunity to reflect on all aspects of our system supporting teacher professionalism. Almost a decade on from 'Teaching Scotland's Future', this collection provides essential reading, whatever your role or interest in the preparation of teachers, and offers a catalyst for an integrated approach to future change'.

Pauline Stephen, Director of Education, Registration and Professional Learning, The General Teaching Council for Scotland 


\section{Emerald Studies in Teacher Preparation in National and Global Contexts}

\section{Series Editors:}

Teresa O’Doherty, Marino Institute of Education, Dublin, Ireland Judith Harford, University College Dublin, Ireland Thomas O'Donoghue, University of Western Australia, Australia

Teacher preparation is currently one of the most pressing and topical issue in the field of education research. It deals with questions such as how teachers are prepared, what the content of their programmes of preparation is, how their effectiveness is assessed, and what the role of the 'good' teacher is in society. These questions are at the forefront of policy agendas around the world.

This series presents robust, critical research studies in the broad field of teacher preparation historically, with attention also being given to current policy and future directions. Most books in the series will focus on an individual country, providing a comprehensive overview of the history of teacher preparation in that country while also making connections between the past and present and informing discussions on possible future directions.

\section{Previously published:}

The Emergence of Teacher Education in Zambia

By Brendan Carmody

Teacher Preparation in Ireland

By Thomas O'Donoghue, Judith Harford, Teresa O'Doherty

Teacher Preparation in South Africa

By Linda Chisholm

Historical Perspectives on Teacher Preparation in Aotearoa New Zealand By Tanya Fitzgerald and Sally Knipe

Catholic Teacher Preparation

By Richard Rymarz and Leonardo Franchi 
Teacher Preparation in Northern Ireland

By Séan Farren, Linda Clarke and Teresa O'Doherty

Forthcoming in this series:

Teacher Preparation in Singapore: Different Pasts, Common Future?

By Yeow-Tong Chia, Jason Tan, Alistair Chew

Teacher Preparation in France

By Imelda Elliott and Emeline Lucuit 


\title{
Teacher Preparation in Scotland
}

\author{
EDITED BY \\ RACHEL SHANKS
}

The University of Aberdeen, Scotland

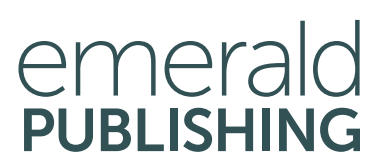

United Kingdom - North America - Japan - India - Malaysia - China 
Emerald Publishing Limited

Howard House, Wagon Lane, Bingley BD16 1WA, UK

First edition 2020

Selection and editorial matter (C) Rachel Shanks. Published under exclusive licence. Individual chapters (C) respective Authors.

\section{Reprints and permissions service}

Contact: permissions@emeraldinsight.com

No part of this book may be reproduced, stored in a retrieval system, transmitted in any form or by any means electronic, mechanical, photocopying, recording or otherwise without either the prior written permission of the publisher or a licence permitting restricted copying issued in the UK by The Copyright Licensing Agency and in the USA by The Copyright Clearance Center. Any opinions expressed in the chapters are those of the authors. Whilst Emerald makes every effort to ensure the quality and accuracy of its content, Emerald makes no representation implied or otherwise, as to the chapters' suitability and application and disclaims any warranties, express or implied, to their use.

\section{British Library Cataloguing in Publication Data}

A catalogue record for this book is available from the British Library

ISBN: 978-1-83909-481-1 (Print)

ISBN: 978-1-83909-480-4 (Online)

ISBN: 978-1-83909-482-8 (Epub) 


\section{About the Editor}

Dr. Rachel Shanks has had a varied career in higher education, community education and trade union education. Her research has focussed on new teacher learning and professional learning through digital technologies while also keeping an interest in community education and children's rights in education. She is a Senior Lecturer and is the University of Aberdeen co-investigator in the Measuring Quality in Initial Teacher Education project in Scotland. 
This page intentionally left blank 


\section{About the Authors}

Dr. Paul Adams' work is primarily concerned with theoretical expositions on education policy. He has published widely in the areas of English and Scottish education policy, in particular when applied to pedagogy and on heuristic proposals for an understanding of policy processes and research. His work uses theoretical positions such as Positioning Theory and philosophy to examine the ways in which policy might be better understood as an essentially intersubjective experience. $\mathrm{He}$ is currently Co-Principal Investigator on the Scottish Government-funded MQuITE project.

Dr. Anna Beck is a lecturer in Teacher Professional Learning at the University of Strathclyde. Her research interests span education policy, education reform and professional learning. She draws on network ethnographic methods in order to uncover policy processes, with a particular focus on the representation of teacher voice. Her current research explores the rise of evidence-based practice in Scotland, England and Germany and the politicisation of teacher research. She is a Co-Investigator on the Scottish Government-funded MQuITE project.

Nicola Carse is a Lecturer in Physical Education at the University of Edinburgh. Her research focusses on teacher education, professional learning, curriculum development, practitioner enquiry and self-study. Nicola is a coinvestigator on a six-year, Scottish Government-funded project entitled 'Measuring Quality in Initial Teacher Education'. Nicola is currently the President of the Scottish Educational Research Association and co-convenes two affiliated networks, the Teacher Education Network and Scottish Physical Education Network.

Dr. Mark Carver is a lecturer in TESOL at the University of St Andrews and research assistant on the Measuring Quality in Initial Teacher Education (MQuITE) project at the University of Edinburgh. Following a PhD looking at feedback in initial teacher education, his research focuses on assessment, including assessment of learners and of programmes. His work in the Scholarship of Teaching and Learning seeking to reconnect TESOL with the educational research community was recognised with a McCall MacBain Foundation Teaching Excellence Award in 2020. 
Robert Doherty is a Senior Lecturer at the University of Glasgow and a coinvestigator in the Scotland-wide Measuring Quality in Initial Teacher Education (MQuITE) project. Robert has a career background that embraces shipbuilding and secondary school teaching. He has a number of research interests including, teacher education, education policy and theories of education.

Sandra Eady, Queen Margaret University Scotland.

Sandra Eady has a strong interest in Teacher Education. She currently leads Education Programmes at Queen Margaret University. She has a number of publications relating to Teacher Education, Mentoring and Partnership working.

Roger Edwards, BSc, is a natural scientist by training, has developed an interest in the history of Glasgow's early Episcopalians and is a founder member of the Scottish Episcopal Church historians' group.

Jennifer Ellis is a Senior Lecturer at the University of the West of Scotland. She is the Programme Leader of the PGDE Primary programme; prior to this, she led the undergraduate ITE programme. She has published on the topic of active learning in primary schools and is engaged in research into the quality of initial teacher education in Scotland.

Moira Hulme is a Professor of Teacher Education at the Education and Social Research Institute, Manchester Metropolitan University. Before this, she was a Senior Lecturer in Educational Research at the Robert Owen Centre for Educational Change, University of Glasgow. Teacher education policy is the primary focus of her research. She is interested in international, comparative and historical studies. She currently leads the Manchester Master of Teaching (MTeach) programme, instituted in 2020.

Walter Humes has been a Professor of Education at the Universities of Aberdeen, Strathclyde and West of Scotland. He is now an Honorary Professor at the University of Stirling. His publications include work on curriculum studies, policy analysis, history of education, teacher education and educational leadership. He is co-editor of Scottish Education, a 1000-page volume covering all sectors of the Scottish educational system (5th edition, 2018). In 2019, he was awarded a John Nisbet Fellowship by the British Educational Research Association for his contribution to educational research.

David H. Johnston is a Lecturer in Literacy and Education at the University of Aberdeen, having been a secondary school English teacher for 17 years. His research interests are in student teachers' experiences on school placement and he has published in this area since 2010.

Aileen Kennedy is Professor of Practice in Teacher Education at the University of Strathclyde. At the time of writing she was Senior Lecturer at the University of Edinburgh, where she was responsible for the development of an innovative 
new two-year ITE Masters designed from an explicit transformative and activist stance. Her research focuses on teacher education, professional learning, teacher professionalism and policy reform, from a social justice perspective.

Stephen J. McKinney is a professor in the School of Education, University of Glasgow. He leads the research and teaching group, Pedagogy, Praxis and Faith. He is an active researcher and his research interests include Catholic Education, Faith Schooling, the History of Education and the Impact of Poverty on Education. He has produced numerous research articles, reports, books and book chapters on these themes. $\mathrm{He}$ is a visiting professor in Catholic Education at Newman University and a member of the steering group for the Network for Researchers in Catholic Education. He is chair of the Executive of the Association of University Lecturers in Religion and Education and is the past president of the Scottish Educational Research Association. He is a former Co-Editor of the Scottish Educational Review. Recent works include McKinney, S.J. \& McCluskey, R. (Eds.), A History of Catholic Schools and Education in Scotland: New Perspectives. London: Palgrave Macmillan.

Carrie McLennan is a Senior Lecturer at the University of Dundee where she has worked since 2008. As a teacher educator, she has supported students across the primary and secondary sectors. For five years, Carrie managed the MA (Hons) Education in primary teaching and, since 2019, has been Associate Dean of Quality and Academic Standards in the School of Education and Social Work. Originally qualified as a Modern Languages teacher, Carrie worked in a range of local authorities in Scotland before moving to higher education sector. Her areas of scholarship focus on teacher education, pedagogy, languages and quality assurance in higher education. She is currently Academic Secretary and trustee of the Scottish Educational Research Association.

Rachel Shanks is a Senior Lecturer at the University of Aberdeen and is the Aberdeen co-investigator in the MQuITE project. She has worked in higher education, community education and the voluntary and trade union sectors. Her doctoral research explored how new teachers in Scotland learn in the workplace. Her research interests include professional learning, community education and children's rights in education.

Morag Redford, University of the Highlands and Islands, Scotland

Morag Redford is currently a Professor of Teacher Education and Head of Teacher Education in the University of the Highlands and Islands. In this post, she has led the expansion of initial and continuing teacher education programmes across the rural region of the University, working through the digital infrastructure of the University to provide programmes for teachers in rural Scotland. Her research interests focus on partnership work between schools and universities, the political administration of education in Scotland and practice-based research 
with rural schools. This work builds on her practice experience in primary and secondary schools and previous posts in the University of Stirling where she was Director of Professional Learning responsible for the provision of master's programmes for practising teachers. 


\section{Table of Contents}

Introduction: Development of Teacher Preparation in Scotland Rachel Shanks

Chapter 1 Teacher Preparation in Scotland, 1872-1920 Moira Hulme

Chapter 2 Re-shaping Teacher Preparation in Scotland: Curricular, Institutional and Professional Changes, 1920-2000

Walter Humes

Chapter 3 Teacher Preparation Post-devolution, 1999-2007 49

Carrie McLennan

Chapter 4 The Donaldson Report, Partnership and Teacher Education

Anna Beck and Paul Adams

Chapter 5 Bachelor's Degrees in Education

Sandra Eady

Chapter 6 Professional Graduate Diploma in Education Jennifer Ellis

Chapter 7 School Placement: Problematising Notions of the 'Good' Placement

David H. Johnston 
Chapter 8 Online and Distance Teacher Preparation

Chapter 11 Catholic Teacher Preparation 165

Stephen J. Mckinney

Chapter 12 A Concise History of the Episcopal Teacher Training College in Scotland

Stephen J. Mckinney and Roger Edwards

Chapter 13 English Language Teacher Preparation

Mark Carver

Conclusion: Caledonian Teacher Education Futures

Robert Doherty

Index 


\section{List of Abbreviations or Acronyms}

$\begin{array}{ll}\text { ADES } & \text { Association of Directors of Education in Scotland } \\ \text { BA } & \text { Bachelor of Arts } \\ \text { BEd/EdB } & \text { Bachelor of Education } \\ \text { BERA } & \text { British Educational Research Association } \\ \text { CEC } & \text { Central Executive Committee } \\ \text { CfE } & \text { Curriculum for Excellence } \\ \text { CLPL } & \text { Career-Long Professional Learning } \\ \text { CNAA } & \text { Council for National Academic Awards } \\ \text { CPD } & \text { Continuous Professional Development } \\ \text { EAL } & \text { English as an Additional Language } \\ \text { EFL } & \text { English as a Foreign Language } \\ \text { EIS } & \text { Educational Institute of Scotland } \\ \text { ELT } & \text { English Language Teaching } \\ \text { ESL } & \text { English as a Second Language } \\ \text { ESOL } & \text { English for Speakers of Other Languages } \\ \text { GIRFEC } & \text { Getting It Right For Every Child } \\ \text { GME } & \text { Gaelic-medium education } \\ \text { GTCS } & \text { General Teaching Council for Scotland } \\ \text { HEIs } & \text { Higher Education Institutions } \\ \text { HMI } & \text { Her Majesty's Inspectors } \\ \text { HMIE } & \text { Her Majesty's Inspectors of Education } \\ \text { ITE } & \text { Initial Teacher Education } \\ \text { MA } & \text { Master of Arts } \\ \text { MQuITE } & \text { Measuring Quality in Initial Teacher Education } \\ \text { NCTT } & \text { National Committee for the Training of Teachers } \\ \text { NQT } & \text { Newly qualified teachers }\end{array}$


ODL

OECD

PGCE

PGDE

QAAHE

QMU

SBTE

SCQF

SCTT

SED

SEED

SERA

SFC

SFR

SHEFC

SNCT

SOED

SPR

SPS

SQA

STEAC

TCs

TEFL

UHI

UNESCO
SCDE

Online and Distance Learning

Organisation for Economic Co-operation and Development

Postgraduate Certificate in Education

Professional Graduate Diploma in Education

Quality Assurance Agency Higher Education

Queen Margaret University

Strategic Board for Teacher Education

Scottish Council of Deans of Education

Scottish Credit and Qualifications Framework

Scottish Council for the Training of Teachers

Scottish Education Department

Scottish Executive Education Department

Scottish Educational Research Association

Scottish Funding Council

Standard for Full Registration

Scottish Higher Education Funding Council

Scottish National Committee for Teachers

Scottish Office Education Department

Standards for Provisional Registration

Student Placement System.

Scottish Qualifications Authority

Scottish Tertiary Education Advisory Council

Training Centres

Teaching English as a Foreign Language

University of the Highlands and Islands

United Nations Educational, Scientific and Cultural

Organisation

UWS University of the West of Scotland 